\title{
INTENSITAS KOMUNIKASI TOKOH PUBLIK MELALUI PENDEKATAN HUBUNGAN KEKERABATAN UNTUK MENCEGAH PENYIMPANGAN SOSIAL
}

\author{
Dodot Sapto Adi \\ Ana Mariani \\ Program Studi Ilmu Komunikasi Universitas Merdeka Malang \\ dodotrebelian@gmail.com \\ ana.mariani@unmer.ac.id
}

\begin{abstract}
This article is intended to provide a description of research results on the intensity of public figure communication through the approach of familial relationships to prevent social deviation. This study is a literature review study or literature study based on some previous research results by combining factual analysis. The results of this study can reveal the intensity of communication public figures are able to prevent and cope with social impediment in a social group. Where the heaviest of deviations is labeling which is the cause and effect of the explanation itself. Social deviation is examined from two aspects namely lifestyle and culture in social groups. The intensity of communication of public figures always reflects the closeness of the relationship between the elements of the system within the society, and is able to contribute through efforts to improve the existing conditions in the normative state. The higher the intensity of communicating, the higher the togetherness is created through new forms of agreement. The main determinant is the intensity of communication by public figures and communication approaches based on kinship relationships.
\end{abstract}

Key Words: Communication Intensity, Public Figure, Kinship Relations and Social Diversity.

\begin{abstract}
Abstrak
Artikel ini ditujukan untuk memberikan deskripsi hasil penelitian tentang intensitas komunikasi tokoh publik melalui pendekatan hubungan kekeluargaan untuk mencegah penyimpangan sosial. Penelitian ini merupakan penelitian kajian pustaka aatau studi literatur yang berbasis pada beberapa hasil penelitian terdahulu dengam mengkombinasikan analisis faktual. Hasil penelitian ini mampu mengungkapkan intensitas komunikasi tokoh public mampu mencegah serta menanggulangi peyimpangan sosial dalam sebuah kelompok sosial. dimana hal terberat dari penyimpangan adalah pelabelan yang merupakan penyebab serta akibat dari penyimbapangan itu sendiri. Penyimpangan sosial dikaji dari dua aspek yakni gaya hidup dan budaya dalam kelompok sosial. Intensitas komunikasi tokoh publik selalu mempertimbagkan tingkat keeratan hubungan elemen sistem di dalam tatanan masyarakat, dan ternyata mampu memberikan kontribusi melalui upaya untuk memperbaiki kondisi yang ada dalam keadaan normatif. Semakin tinggi intensitas berkomunikasi, maka semakin tinggi pula kebersamaan tercipta melalui bentuk-bentuk kesepakatan baru. Yang menjadi penentu utamnaya adalah intensitas komunikasi yang dilakukan tokoh publik serta pendekatan komunikasi yang berbasis pada hubungan kekerabatan.
\end{abstract}

Kata kunci: Intensitas Komunikasi, Tokoh Publik, Hubungan Kekerabatan dan Penyimpangan Sosial. 


\section{PENDAHULUAN}

Tokoh publik menjadi pusat dari komunikasi yang terjalin dalam sebuah kelompok masyarakata. Sehingga dalam pola komunikasi hingga intensitas komunikasi mereka menjadi indikator penentu dalam penyelesaian permasalahan sosial dalam sebuah kelompok, terlebih terkait dengan tindakan penyimpangan sosial. Komunikasi dengan pendekatan yang berbasis kekeluargaan sudah mulai sulit ditemukan dalam kehidupan masyarakat modern. Komunikasi tersebut memiliki peranan penting untuk menciptakan perubahan sosial dalam sebuah kelompok. Disamping persaingan global, perubahan sosial juga semakin dinamis sebagai imbas dari modernisasi. Dinamia sosial yang terbentuk tersebut akan melahirkan potensi tindakan penyimpangan sosial. Penanganan perrmasalahan penyimpangan sosial dipengaruhi oleh kedekatan personal tokohtokoh publik dalam lingkungan sosial yang lebih kompleks. Interaksi sosial yang terjalin antar tokoh publik tersebut menstimulasi terciptanya keseimbangan sosial.

Tingkat keeratan hubungan masingmasing sub sistem di dalam tatanan masyarakat akan mampu memberikan kontribusi frekuensi dan intensitas komunikasi yang dilakukan oleh tokoh publik. Hal ini disebabkan penyimpangan sosial sering kali ditengarai dan identik dengan penyakit sosial yang dilakukan oleh masyarakat marjinal dan masyarakat yang terdiskriminasi oleh aturan kelompok sosial. Faktor yang bisa menjadi jembatan untuk mengatasi hal tersebut adalah tokoh publik, dimana melalui interaksi yang dibangun dengan pendekatan komunikasi kekerabatan akan mudah diterima oleh seluruh kalangan kelompok sosial baik kelompok mayoritas maupun minoritas. Penekanan penelitian ini ada pada interaksi sosial tokoh publik yang menggunakan komunikasi pendekatan kekeluargaan untuk mencegah tindakan penyimpangan sosial dalam sebuah kelompok sosial.

\section{TINJAUAN PUSTAKA}

\section{Tokoh Publik dan Komunikasi Pendekatan Hubungan Kekerabatan}

Dalam hasil studi Muzayin (2014) menyebutkan bahwa terdapat beberapa perubahan penting yang terjadi akibat dari modernisasi antara lain perubahan sistematis, perubahan fungsional dan perubahan sikap dalam masyarakat tradisional (Abraham, 1991:17-25), dapat dijelaskan sebagai berikut:

a. Perubahan Sistematis Perubahan sistemis berpengaruh pada perubahan perilaku masyarakat modern, terutama perubahan dalam keluarga.

b. Perubahan Fungsional Modernisasi juga berpengaruh terhadap perubahan fungsional dalam menciptakan profesi baru dan mengakibatkan perubahan.

c. Perubahan Sikap Modernisasi tidak hanya meliputi peningkatan diferensiasi sistem sosial, tetapi juga transformasi progresif dalam sikap pelaku sosial.

Secara vertikal direpresentasikan melalui pelapisan kelas sosial atas sampai dengan bawah. Segala hal yang menggambarkan tingkah laku individu tampak dalam suatu kenyataan, dan berlangsung dalam bentuk keajegan berpola yang muncul secara berkala, sehingga dapat dipahami sebagai suatu fenomena yang bersifat tetap. Struktur 
sosial dilandasi dua ciri keunikan, secara horizontal merupakan representasi kesatuan sosial (social unity) yang menggambarkan perbedaan suku bangsa, agama, adat istiadat serta asal-usul kedaerahan. Unsur-unsur kesamaan tersebut akhirnya mengarah pada suatu kesadaran bersama, bahwa terdapat kondisi dinamis dengan mengindikasikan berbagai persoalan yang menyangkut individuindividu bahkan sampai dengan persoalan kelompok (Nasikun, 2001).

Karakter yang ditampilkan melalui tingkah laku pada setiap lapisan masyarakat dengan berbagai jenis pekerjaannya juga tergambarkan, dan paling menarik ketika dihadapkan pada individu-individu yang memiliki profesi bersentuhan rekat (manifest) maupun terselubung (latent) dengan kegiatan seks komersial. Sebagaimana diskusi publik dalam berbagai media massa dan sosial lainnya, juga masih memiliki intensitas yang relatif sangat tinggi memperdebatkan profesi terselubung seperti ini, sehingga diperlukan adanya kebijakan yang cenderung memiliki sifat berkeadilan bagi profesi terlarang. Bahkan intensitas tinggi juga mengarah pada opini yang kurang seimbang, yaitu timbulnya upaya diskriminatif dalam memberi perlakuan kepada perempuan, dengan bentuk-bentuk pengkondisian yang melibatkan urusan individu (privacy), pengungkapan pengalaman pribadi secara terbuka, harapan masa depan dari ketertindasan, sampai dengan perilaku yang disalah-maknai sebagai gaya hidup. Hal ini kadangkala diungkap sebagai praktik budaya dalam sistem sosial modern, meskipun sebenarnya pihak tertentu menilai adanya kekurangpatutan untuk dipublikasikan.

Burgest dan Locke (1960) dalam Herien Puspitawati (2013) ciri keluarga merupakan kesatuan dari orang-orang yang berinteraksi dan berkomunikasi yang menciptakan peranan-peranan sosial. Peranan-peranan tersebut diperkuat oleh kekuatan tradisi dan sebagian lagi emosional yang menghasilkan pengalaman; selain itu keluarga adalah pemelihara suatu kebudayaan bersama yang diperoleh dari kebudayaan umum. Stephens mendefiniskan keluarga sebagai suatu susunan sosial yang bersifat reciprocal.

Pendekatan kekeluargaan berbasis konsep diatas merupakan pondasi terciptanya kerjasama diantara elemen masyarakat guna mencari solusi terbaik atas permasalahan penyimpangan sosial. Kultur dan gaya hidup masyarakat juga turut serta mepengaruhi proses pencegahan penyimpangan sosial. Penyimpangan sosial dipahami sebagai tindakan yang dilakukan oleh individu atau kelompok sosial yang tidak sesuai atau melawan kaidah-kaidah yang berlaku dalam masyarakat. Kaidah yang berlaku di masyarakat tersebut berwujud nilai dan norma yang mengatur perbuatan mana yang boleh dilakukan dan tidak boleh dilakukan.

Menurut Paul B. Horton dan Chester L. Hunt (1996), ciri-ciri yang bisa diketahui dari perilaku menyimpang sebagai berikut:

a. Suatu perbuatan disebut menyimpang bilamana perbuatan itu dinyatakan sebagai menyimpang.

b. Penyimpangan terjadi sebagai konsekuensi dari adanya peraturan dan penerapan sanksi yang dilakukan oleh orang lain terhadap si pelaku menyimpang.

c. Ada perilaku menyimpang yang bisa diterima dan ada yang ditolak.

d. Mayoritas orang tidak sepenuhnya menaati peraturan sehingga ada bentuk 
penyimpangan yang tersamar dan ada yang mutlak.

e. Penyimpangan bisa terjadi terhadap budaya ideal dan budaya riil. Budaya ideal merupakan tata kelakuan dan kebiasaan yang secara formal disetujui dan diharapkan diikuti oleh anggota masyarakat. Sedangkan budaya riil mencakup hal-hal yang betul-betul mereka laksanakan.

f. Apabila ada peraturan hukum yang melarang suatu perbuatan yang ingin sekali diperbuat banyak orang, biasanya muncul norma penghindaran

Kondisi ini memunculkan pemikiran, bahwa diperlukan pendekatan kekeluargaan yang dilakukan oleh tokoh publik untuk meningkatkan kesadaran seluruh individu dalam sistem sosial. Kesadaran bersama merupakan produk dari persepsi yang sama, dilandasi oleh normanorma yang dibangun dan dipelihara bersama pula. Apabila setiap pergeseran nilai-nilai normatif sudah menjadi komitmen bersama, maka pada tahap selanjutnya akan melahirkan nilai-nilai baru diyakini bersama pula yang lazimnya disebut dengan memiliki permasalahan internal bersama. Dan hal tersebut mampu menggeser tingginya tingkat penyimpangan sosial yang terjadi dalam sistem kelompok sosial.

Pandangan strukturalis memposisikan tokoh publik pada perspektif lokal termasuk di dalam pemahaman tokoh masyarakat, memiliki pengaruh serta dihormati bisa dipandang dari sisi kekayaannya, pengetahuannya, budi pekertinya atau kesuksesannya dalam menjalani kehidupan (leadership in lifeworld). Referensi inilah seringkali menjadikannya sebagai panutan bagi banyak orang dalam interaksi dan pertukaran sosial, sebagaimana studi yang dilakukan oleh Ritzer (1996), bahwa aktor dalam proses sosial disebut sebagai tokoh (individu lain maupun kelompok terbatas) yang memiliki sumberdaya tinggi, khususnya untuk menciptakan kesempatan melakukan inisiasi dan negosiasi sampai dengan tercapainya permufakatan yang dilandasi rasa saling ketergantungan (interdependencies), ada keterpaduan (integration), maupun ada keeratan (cohession,) dan sebagai komitmen akhir (internal relationship). Dalam aspek ekonomi, tokoh publik akan mampu merekatkan hubungan masyarakat di dalam suatu wilayah tertentu (external relationship). Fungsinya pada upaya memberdayakan maupun membangun masyarakat menuju mandiri dan berdaya guna, sedangkan dalam aspek agama bagi tokoh publik memberikan sumbangsih pada pemikiran maupun keyakinan (Ritzer \& Smart, 2012).

Keleluasan tokoh publik melakukan pendekatan dalam rangka menciptakan kesadaran sosial, tidak hanya atas dasar sukarela, tetapi ada muatan tertentu yang dijadikan dasar sebuah langkah yang berkelanjutan, salah satunya melalui pendekatan askripstif meskipun belum diposisi menonjol dominasinya. Pendekatan askriptif digunakan untuk mengungkap lebih jauh tentang sebuah hubungan yang terjalin, pada awalnya menekankan sifat kekeluargaan lebih memungkinkan menjadi efektif dengan ditunjang kemampuan berkomunikasi, sehingga bisa menyampaikan maksud secara terbuka dengan mengedepankan emphatic understanding, sehingga bisa diharapkan tumbuh kesadaran normatif (Rogers, 1972 dalam Borden \& Stone, 1976). Sebagaimana diungkap oleh Parsons melalui studinya yang menghasilkan 
variabel pola, telah merumuskan mekanisme berbanding terbalik atau berlawanan (versus concept) dalam proses interaksi secara fungsional diantara achievement versus ascription, yaitu terdapat pertimbangan yang rumit dalam setiap tindakan individu dalam rangka memenuhi kebutuhan sesuai dengan harapan-harapannya. Ditemukan ada fenomena-fenomena yang mengarah pada pilihan tindakan yang berproses memenuhi kebutuhan yang memperoleh dorongan secara dominan dari sisi rasio (rational judgement), namun sebaliknya juga masih banyak berkembang khususnya di dalam masyarakat transisi yang lebih mengedepankan pertimbangan yang emosional (moral orientation). Hal ini tentunya tidak bisa dilakukan oleh sembarang orang tanpa memiliki bekal keahlian retorika sosial, dan pasti membutuhkan campur tangan tokoh publik memiliki wawasan yang luas dengan didukung oleh kemampuan berkomunikasi (Ritzer, 2012).

\section{Penyimpangan Sosial}

Ditengah himpitan modernisasi yang memicu berbagai macam tindakan penyimpangan sosial dalam sebuah kelompok sosial, intensitas komunikasi yang dilakukan tokoh publik menjadi satusatunya instrumen paling ampuh dan terpercaya, khususnya menentukan derajat ketokohan seseorang untuk dapat diterima oleh semua kalangan dalam rangka mengatasi problematika sosial yang ada. Disamping itu juga dalam rangka mengubah problematika lingkungan sosialnya menjadi potensi unggulan yang menjadi harapan seluruh masyarakat. Sebagaimana penelitian yang telah dilakukan oleh Djatmikowati (2011) mengungkapkan, Sebenarnya para pelaku penyimpangan sosial menyadari tentang tindakannya yang melanggar norma-norma sosial, dan tidak ingin menularkan tindakan menyimpang mereka ke keluarganya, namun ketidakberdayaan memasuki lingkungan yang dinilainya normal belum memiliki bekal yang cukup atau memadai. Tindakan preventif mencegah kegiatan tersebut, didukung oleh tokoh tua sampai dengan tokoh kepemudaan terlibat di dalamnya. Pada prinsipnya masih besar peluang untuk optimis mengubah kecenderungan tindakan penyimpangan sosial dengan memastikan adanya upaya mencegah tindakan penyimpangan sosial dalam kelompok sosial.

Penyimpangan sosial sendiri sering kali digolongka oleh masyarakat sebagai penyakit masyasrakat yang mengancap kenyamanan dan keamanan sistem sosial dalam kehidupan bermasyarakata. Labeling menurut Henslin (2007) adalah pemberian label kepada seseorang yang menjadi bagian dari konsep diri seseorang. Label yang akan diberikan kepada seseorang itu akan cenderung melanjutkan penyimpangan tersebut. Label tersebut dapat berasal dari ciri fisik yang menonjol (misalnya belang dan cacat), karakter (misalnya homoseksualitas), kelompok sosial (misalnya ras atau bangsa). Pemberian label tersebut biasanya didapat dari hasil interaksi sosialnya.

Kemudian F.M. Lemert (Erianjoni, 2014:130), terkait dengan masalah kejahatan yang dilakukan, membedakan tiga bentuk penyimpangan, yaitu:

(a) Individual deviation, dimana timbulnya penyimpangan diakibatkan tekanan psikis dari dalam;

(b) Situational deviation, sebagai hasil stres atau tekanan dari keadaan; dan 
(c) Systematic deviation, sebagai pola-pola perilaku kejahatan terorganisir dalam sub-sub kultur atau sistem tingkah laku.

Dalam Heselin (2007) Empat perilaku menyimpang dalam kelompok menyasar aspek personal maupun kelompok, antara lain: inovasi (innovation), ritual (ritualism), peneduhan hati (retreatism), dan pemberontakan (rebellion). Yang dimaksud inovasi adalah perilaku seseorang yang menerima atau mengakui tujuan yang selaras dengan budaya atau diinginkan masyarakat. Sedangkan inovasi merupakan tindakan mengembangkan sesuatu yang sudah ada menjadi sesusatu yang baru. Demikian juga, seseorang yang menolak cara-cara wajar dalam menjalani kehidupannya, maka dalam sosiologi, perilaku ini juga dikategorikan sebagai sebuah inovasi, tetapi dalam arti negatif. Ritualisme terjadi manakala seseorang menerima cara-cara yang diperkenankan secara kultural tetapi menolak atau mengganti tujuan sehingga berbeda dengan harapan semula dari masyarakat atau kelompok. Pengasingan diri (retreatment) terjadi jika seseorang menolak atau tidak mengakui lagi

baik tetapi tidak mampu untuk melawan arus untuk melakukan perubahan. Sedangkan pemberontakan terjadi ketika ketiga aspek tersebut tidak terpenuhi. Pemberontakan merupakan tindakan melawan sistem yang sudah terbentuk dan dianggap sebagai jalan terakhir untuk melakukan perubahan dalam sebuah kelompok sosial.

\section{HASIL DAN PEMBAHASAN}

\section{Intensitas Komunikasi Tokoh}

Penempatkan tokoh publik sebagai penyedia ruang intensitas sampai dengan terjadinya suatu perubahan yang dikehendaki. Dalam artian bahwa tokoh publik bisa dikatakan sebagai penentu dan pemecah permasalahan sosial dalam sebuah kelompok sosial. Derajat pengaruh tokoh publik menjadi salah satu penentu besar tidaknya peran dan pengaruh dari tokoh publik tersebut. Hal ini telah berproses secara permanen dari waktu ke waktu yang lain pula, akan membentuk pola tersendiri dalam struktur sosial serta selanjutnya akan berkembang sesuai dengan norma sosial yang ada. Semakin tinggi intensitas berkomunikasi, maka semakin tinggi pula kebersamaan tercipta melalui bentukbentuk kesepakatan baru. Dengan demikian struktur sosial yang sudah terbangun ini, selalu dipelihara dan dikembangkan secara inovatif oleh tokoh-tokoh publik yang memiliki kepentingan untuk mencegah timbulnya tindakan penyimpangan sosial dalam kelompok sosial. Tujuan yang lebih spesifik adalah guna memelihara serta mengembangkan struktur sosial sebagai syarat mutlak bagi tumbuhnya institusi sosial, karena dari situlah sistem personal sebagai mekanisme pemeranan individu berubah dengan sendirinya menjadi sebagai himpunan individu dalam rangka menggagas setiap ide untuk memenuhi kebutuhan.

Bagi para tokoh publik, situasi yang berkembangan dijadikan sebagai arena pemeranan interaksional, yaitu untuk menguatkan posisi serta tingkat status sosialnya dengan berbekal pada kepercayaan masyarakat. Demikian pula dalam melaksanakan fungsinya sebagai tokoh publik akan berdampak besar pada perubahan sosial yang diharapkan. Peranan tokoh publik ditentukan oleh bentuk-bentuk persuasi dan karakteristik dari setiap 
individu dalam kelompok sosialnya. Sehingga sasaran sosial yang utama adalah pelaku penyimpangan sosial dalam artian mereka terkategorisasi sebagai pelaku individu maupun kelompok.

Tokoh publik memiliki ruang yang besar untuk mengembangkan intensitas komunikasi dapat selaras dengan peran sosialnya, semakin tampak ketika mengedepankan komunikasi yang berdasarkan atas pendekatan hubungan kekerabatan. Namun, prinsip dasar tidak ditinggalkan yakni pendekatan yang bersifat dinamis tersurat (manifest) maupun dinamis tersiratkan (latent), karena untuk memenuhi suatu tuntutan efektifitas berkomunikasi diantara para tokoh publik sendiri (tingkatan setara), dan mengembangkan komunikasi dengan sasarannya yang terdiri dari pelaku dan pengelola hiburan karaoke (tingkatan vertikal). Tokoh publik atas dasar kesadarannya sendiri semakin dituntut mengembangkan kreativitas sebagai pelopor yang jelas memiliki niatan baik, dengan menetapkan sasaran yang sangat jelas sebagai tujuan dalam memperoleh posisi sosial (achievement), menerapkan intensitas komunikasi dengan menggunakan pendekatan personal maupun kelompok untuk mencapai tujuannya tersebut, dan selanjutnya mengembangkan inovasi secara perlahan guna memelihara hubungan sosial yang lebih permanen. Hanya dengan intensitas komunikasi yang dilakukan oleh tokoh publik, sampai pada tahapan akhir dengan memperoleh kepercayaan dari seluruh masyarakat sasaran (ascription).

\section{Pelabelan Penyimpangan Sosial dan Intensitas Komunikasi Tokoh Publik}

Tokoh publik memiliki jiwa sosial yang tinggi dengan selalu membantu memberikan sentuhan kemanusiaan dalam setiap solusi yang dihasilkan. Atmosfer yang diciptakannya membuat suasana lebih kondusif. Menghindari timbulnya ego masing-masing, namun berupaya membangun suasana dialogis. Demikian pada lokasi penelitian yang memiliki kecenderungan masih sangat bergantung, dan relatif patuh pada orang yang lebih tinggi kedudukannya seperti pada tokoh publik. Dengan kata lain memiliki daya tawar (bargaining position) yang lebih tinggi. Dari kondisi ini, pihak tokoh publik diuntungkan, karena menurut tinjauan komunikasi dan negosiasi lawan bicara yang memiliki daya tawar rendah akan mudah diarahkan dalam rangka pengendalian sosial menjadi sangat mudah. Hal ini sejalan dengan temuan hasil penelitian yang telah dilakukan oleh Satriani dan kawan-kawan (2011), bahwa dalam menyelesaikan masalah sosial secara komunikasi dialogis lebih menjamin diperolehnya kesepakatan bersama, mengingat tatap muka yang terjadi melahirkan rasa untuk saling menghargai sesama insan, bahkan menimbulkan rasa tanggung jawab bersama, dan selanjutnya berdampak pada pemberdayaan sosial. Dialog merupakan proses yang tepat dalam penyelesaian masalah, mengatasi kendala atau hambatan dalam proses pengambilan keputusan.

Kendala terbesar dalam menghadapi atau memecahkan permasalahan penyimpangan sosial pada kelompok sosial adalah ada pada penghilangan sebuah pelabelan. Sebab pelabelan merupakan permasalahan mendasar bahkan bisa dikatan sebagai permasalahan inti dari penyimpangan 
sosial. Pelabelan sekaligus bisa dianggap sebagai pemicu dan akibat dari penyimangan sosial, jika digambarkan seperti siklus yang tidak kunjung ada ujungnya. Pelabelan bisa dikaitkan dengan dua faktor yakni gaya hidup dan budaya yang menjangkit dalam kelompok sosial. terlebih jika pelabelan tersebut dikaitkan dengan gender dan strata sosial dalam tatanan kelompok sosial.

Istilah yang mudah dipahami untuk menggantikan kata pelabelan adalah tuduhan yang tidak diinginkan oleh para pelaku penyimpangan sosial. Keterlibatan tokoh publik mellaui pola komunikasi dan intensitas komunikasi yang dijalin mampu membantu mengurangi pelabelan. Hal terpenting yang dapat dilihat adalah bahwa komunikasi yang berbasis pada pendekatan hubungan kekerabatan mampu menghilangkan pelabelan yang terjadi pada pelaku penyimpangan sosial.

Pada dasarnya segala situasi dan kondisi yang demikian ini, akan mudah dilakukan intervensi perubahan sosial terlebih dengan pendekatan yang berlandasakan atas hubungan kekerabatan. Mengedepankan komunikasi yang berasaskan kekeluargaan menjadi jaminan lebih kondusif. Kecenderungan berkomunikasi dengan pola tertutup biasanya dilakukan oleh masyarakat yang memiliki tingkat pendidikan dan ekonomi yang rendah, sehingga permasalahan sebenarnya terdapat pada kesadaran yang sifatnya normatif, dan jauh lebih patuh pada norma serta nilai yang sudah disepakati bersama sesuai dengan kaidah dasar yang berlaku di lingkungan sosialnya.

\section{Komunikasi Pendekatan Hubungan Kekeluargaan}

Dalam menyelesaikan sebuah konflik sosial maupun permasalahan sosial, tokoh publik sering kali memainkan pola persuasi personal yang syarat akan nilai atau asas kekerabatan. Sebab tokoh publik dianggap sebagai perwakilan atau representasi dari sebuah kelompok sosial. Pola persuasi personal juga dilakukan untuk memperoleh kepengikutan dari kelompok sosialnya. Konteks komunikasi secara personal maupun kelompok yang berbasis hubungan kekerabatan dilandasi oleh tata krama kearifan lokal yang dianut bersama. Ketertundukan masyarakkat terhadap tokoh publik sangat terasa dalam proses komunikasi, dengan memposisikan diri sendiri sebagai yang lebih rendah stratanya dibandingkan dengan posisi tokoh publik.

Anggota dalam sebuah kelompok sosial bisa dikategorikan sebagai berikut: komunitas membedakan diantara dua jenis komunitas. Pertama adalah komunitas tradisional yang mengacu pada wilayah atau geografis. Pada titik ini komunitas mengacu pada lingkungan tempat tinggal, kota, atau daerah. Kedua adalah komunitas rasional yang mengacu pada hubungan manusia tanpa kaitan dengan lokasi. Sebagai contoh, ada beberapa komunitas yang memiliki ketertarikan seperti klub hobi, grup agama, atau klub penggemar. Tetapi kedua tipe komunitas ini tidak saling mengesklusifkan, banyak grup yang berdasarkan ketertarikan tetapi merangkap sebagai komunitas yang berbasiskan dengan lokasi manusia tinggal (Algesheimer, 2005).

Pendekatan yang menekankan pada hubungan kekerabatan mampu menjadi jembatan antara dua komunitas tersebut. Inilah alasan tokoh publik sering menggunakan komunikasi dengan pendekatan kekeluargaan untuk mengatasi permasalahan penyimpangan sosial dalam 
kelompok sosial yang mereka pimpin. Komunikasi yang lebih menonjolkan nilainilai kekeluargaan dengan saling menyapa sebagaimana layaknya bagian dari kehidupan sosial sehari-harimenjadi pengendali sikap anggota kelompok sosial dan mempengaruhi perilaku lewat proses pengambilan keputusan yang teliti dan beralasan. Dampaknya terbatas pada tiga faktor. Pertama, perilaku tidak banyak ditentukan oleh sikap umum tapi oleh sikap yang spesifik terhadap sesuatu. Kedua, perilaku dipengaruhi tidak hanya oleh sikap tetapi juga oleh norma-norma subjektif (subjectiveness norms) yaitu keyakinan mengenai yang orang lain inginkan agar dijadikan referensi untuk tindakan selanjutnya. Ketiga, sikap terhadap suatu gambaran norma-norma subjektif membentuk suatu interest dengan dilandasi niat untuk berperilaku tertentu (Azwar, 1997). Hal ini senada dengan hasil penelitian Bahtiar (2012), bahwa peran yang tinggi tetapi tidak didasari dengan sikap yang positif, ataupun sebatas pada sikap yang positif, tetapi belum dicerminkan secara terperinci dalam berbagai perannya, maka hal tersebut tidak memiliki dampak signifikan apapun. Sedangkan sebagai tokoh masyarakat sudah pada fungsi penggerak perubahan normatif, dan seharusnya segera melakukan perubahan kondisi sosial menjadi lebih baik lagi agar lebih memiliki makna.

Pendekatan tindakan sosial memberikan arahan tentang kehidupan yang banyak diliputi ketergantungan seseorang pada situasi perasaan, yaitu menempatkan unsur rasa diri sebagai bagian yang tidak terpisahkan dalam menentukan sikapnya diantara orang lain. Pendekatan tersebut, adalah yang mendominasi perilaku seseorang untuk menurunkan derajat rasionalitasnya dengan alasan ketidaktepatan dalam memenuhi harapannya sendiri, sehingga pendekatan ini tidak memungkinkan fakta dapat dikaji secara mendalam dengan dilandasi kekuatan akal sehat, namun lebih tepatnya pendekatan irrasional berperasaan (ascriptive awareness) yang menjadi pilihan utama dalam rangka memecahkan setiap persoalan. Problematika tindakan sosial selalu mempertanyakan aktor bertindak seperti yang dilakukannya saat itu, sejauh mana tindakan aktor ditentukan oleh pengaruh-pengaruh yang ada di luar kendalinya, disengaja atau tidak. Parsons juga beranggapan bahwa tindakan individu dan kelompok itu dipengaruhi oleh sistem sosial, sistem budaya, dan sistem kepribadian. Dengan demikian ada hubungan fungsional pada setiap tindakan, namun menyatu dalam lingkungan terstruktur (Ritzer, 2012).

$$
\text { Tokoh publik dalam }
$$

mengintensifkan tindakan komunikasinya menghindari sebagai wakil dari pihak manapun, karena bertindak bukan atas nama pemerintah maupun golongan tertentu yang dengan tegas melarang adanya praktek prostitusi baik secara terbuka maupun terselubung. Tokoh publik bertindak atas kesadaran diri dan lingkungan sosialnya, sehingga tindakan preventif sebagai upaya pencegahan membutuhkan keterlibatan seluruh elemen masyarakat. Demikian pula tokoh di lingkungan pemuda berusaha pula untuk giat menyelenggarakan kegiatan positif secara intensif di wilayah tersebut. Pada lingkup tokoh agama dan pendidikan makin giat pula mengkonsentrasikan beberapa kegiatan yang sifatnya terbuka di wilayah tersebut, yaitu dengan mendatangkan tokoh dari daerah lain. Hampir segala sesuatunya dilaksanakan secara santun dan berkesadaran, agar warga yang tinggal 
paling dekat dengan bekas lokalisasi tetap mau bertahan dan membangun wilayahnya sesuai dengan nilai-nilai dan norma-norma yang berlaku dalam kelompok sosial masing-masing-masing. Pada dasarnya ada dua kelompok yang memikirkan tentang hal tersebut. Kelompok pertama ingin agar kegiatan prostitusi terbuka maupun terselubung harus dihilangkan dari masyarakat. Kelompok kedua ingin agar kondisi tersebut diperbaiki secara efektif. Kelompok pertama dikenal sebagai kelompok moralis, sedangkan kelompok kedua dikenal sebagai kelompok pragmatis (Hull, 1977).

Intensitas komunikasi yang dilakukan tokoh publik dengan asas hubungan kekerabatan adalah untuk mengubah cara pandang masyarakat di dalam maupun di luar sistem sosial. Kerawanan sosial dapat timbul tanpa diduga sebelumnya, apabila frustasi selalu melingkupi emosi warga tidak segera dinetralisasi. Kondisi ini masih perlu pengendalian sosial yang menjadi peran bersama warga lokal yang memerankan tokoh publik sebagai terdepan. Bisa merupakan responsivitas terhadap tekanan psikologis komunal yang berorientasi lingkungan, namun bisa juga pada orientasi personal yang terbentuk dari perkembangan diri.

Tokoh publik memiliki kontribusi besar dalam menciptakan kesejahteraan serta kenyaman sosial, dihormati dan dituakan. Oleh karenanya masyarakat menghargai tokoh publik sebagai orang pertama yang disegani dan dihormati. Berbagai tingkat permasalahan desa selalu melibatkan tokoh publik dalam proses mencegah penyimpangan sosial terselubung. Pendekatan berbasis hubungan kekerabatan tokoh publik secara intensif dilakukan dengan alasan kompleksitas latar belakang kehidupan sasaran komunikasi. Dengan pendekatan yang mengedepankan nilai kekeluargaan, komunikasi yang dilakukan dapat dijamin lebih lebih efektif. Pendekatan yang menggutamnakan asas kekerabatan dapat mempersempit jurang pemisah antara tokoh publik sebagai yang dituakan dengan anggota kelompok sosial. Hal ini sejalan dengan hasil penelitian yang telah dilakukan oleh Indrawati (2015) dengan merumuskan, bahwa dalam kelompok sosial efektif dalam masyarakat yang disebut dengan keluarga, dipastikan memiliki nilai-nilai yang pantas dipedomani, karena memiliki keluhuran dalam memberikan posisi setiap individu untuk berperan. Bahkan nilai-nilai kekeluargaan yang lebih luas disebut dengan keluarga besar, menaungi berbagai status sosial yang berbeda, ternyata mampu juga memberi dampak positif yang efektif, selama memiliki kesadaran untuk mau menguatkan intensitas berkomunikasi. Untuk itu komunikasi harus dilakukan secara konstruktif oleh inisiator yang jelas memliki status sosial lebih tinggi. Dengan dilandasi kasih sayang terhadap sesama serta keakraban diantara yang terlibat di dalamnya, maka komunikasi berjalan secara efektif sebagaimana yang diharapkan bersama, meskipun kuantitasnya sangat sangat besar.

Pro dan kontra atas opini yang tumbuh di masyarakat sebagai suatu isyarat, bahwa reaksi afeksi (perasaan) mulai tertanam dalam diri masing-masing. Demikian pula ditemukannya kelompok netral yang memiliki keunggulan tertentu, dengan memandang setiap persoalan individual yang selalu dilandasi kepentingannya, sehingga intensitas komunikasi personal lebih memungkinkan dari pada kelompok. Pendekatan askriptif 
personal akan mudah dan cepat berdampak pada terciptanya kesamaan cara pandang, sehingga akan membawa proses sosial tersebut menuju keterbukaan, dan pada akhirnya secara terstruktur merembes halus memasuki iklim berfikir secara bersamasama. Kuatnya kebersamaan akan melahirkan pikiran kelompok (groupthink) yang dapat mengikat anggota kelompok (group cohesiveness) walaupun tidak memiliki pandangan yang sama, bahkan pikiran kelompok akan selalu menjadi alasan setiap kelompok lainnya untuk mengikuti kelompok yang lebih kuat landasan berfikir rasional dibandingkan dengan irrasionalnya (Rakhmad, 2012).

Intensitas tokoh publik dalam melakukan komunikasi dengan pendekatan berbasis hubungan kekerabatan yang lebih mengedepankan asas kekeluargaan dan kemanusiaan jauh lebih efektif. Karena sebagai komunikan mereka merasas dianggap sebagai bagian dari sistem dan bukan sebaliknya dijauhkan dari sistem sosial yang dibentuk kelompok sosialnya. Para pelaku penyimpangan sosial merasa lebih dihargai dan menjadi bagian dari sistem, sehingga melalui partisipasi mereka permaslaahan tersebut bisa dicegah. Dengan menggunakan pendekatan yang demikian, membentuk konsep diri sebagai bagian dari masyarakat, dan dapat membangkitkan kesadaran. Hal ini sebagaimana hasil studi yang telah dilaksanakan oleh Munawaroh (2012) dengan mengungkapkan:

1. Konsep diri seseorang dan intensitas komunikasi berperan membentuk tingkat pemahaman dan kesadaran bersama.

2. Semakin rendah intensitas dalam berkomunikasi, maka semakin tinggi pula kecenderungan penyimpangan pemahaman maupun perilaku.

\section{PENUTUP \\ Kesimpulan dan Saran}

Keterlibatan tokoh publik dalam mencegah penyimpangan sosial menjadi indikator utama dalam pemecahan masalah di dalam kelompok sosialnya. Intensitas komunikasi yang dilakukan oleh tokoh publik dengan berdasar pendekatan hubungan kekeluargaan memiliki kontribusi yang besar dalam menciptakan lingkungan sosial yang kondusif. Sebagai stakeholder utama, tokoh publik menjadi tumpuan atas lingkungannya untuk menyelesaikan permasalahan penyimpangan sosial. Terlebih, kelompok sosial selalu mengandalkan komunikasi tokoh publik dengan pendekatan hubungan kekerabatan untuk mengurai kompleksitas latar belakang kehidupan sosial lokal, dengan mengkombinasikan metode musyawarah untuk mempererat ikatan sosial dalam kelompok sosial. Ikatan sosial tergolong sebagai bagian dari hubungan kekerabatan yang dapat digunakan untuk menyederhanakan permasalahan penyimpangan sosial dalam kelompok sosial.

Pencegahan dan penanggulangan penyimpangan sosial lebih efektif dilakukan oleh tokoh publik melalui pola komunikasi yang intens dan berdasar pada pendekatan hubungan kekerabatan. Hal ini dikarenakan asa tersebut mampu mengesamppingkan bahkan menghilangkan pelabelan. Sebab pelabelan dalam penyimpangan sosial dianggap sebagai penyebab sekaligus akibat dari penyimpangan itu sendiri. Sehingga tokoh publik memiliki peranan dan kekuasaan yang besar untuk mengendalikan kelompok sosial mereka dengan menggunakan 
komunikasi dengan pendekatan hubungan kekeluargaan.

\section{DAFTAR PUSTAKA}

Abraham, M. Francis. (1991). Modernisasi di Dunia Ketiga Suatu Teori Umum Pembangunan. (Terjemahan M. Rusli Karim). Penerbit: University Press of America, (Buku asli diterbitkan tahun 1980)

Algesheimer, R. Dholakia, U.M., and Hermann, A. 2005. The Social Influence of Brand Communities: Evidance from Eropean car clubs. Journal of Marketing.

Azwar, Saifuddin. 1997. Sikap Manusia Teori dan pengukurannya. Pustaka Pelajar. Yogjakarta.

Bahtiar, Yanyan. 2012. Hubungan Pengetahuan dan Sikap tokoh Masyarakat Dengan Perannya dalam pengendalian Demam Berdarah di Wilayah Puskesmas kawalu Kota Tasikmalaya. Aspirator Vol. 4 No. 2 Tahun 2012 (Hal. 73 - 84). http://download.

portalgaruda.org/article.php?arti cle $=78890 \& v a l=4901$. Diaskes pada hari Jum'at, 2 Desember 2016, pukul 02:07 pm.

Borden, George A., John D. Stone, 1976.

Human Communication: The

Process of Relating. Cumming Publishing Comp. California.

Bungin, Burhan, 2001. Metodologi Penelitian Sosial. Airlangga University Press. Surabaya

Djatmikowati, Sri Hartini. 2011. Persepsidan Perilaku Sosial Pekerja Seks Komersial. Disertasi Unmer. Malang.

Erijoni. 2014. Pelabelan Etnis Minangkabau Pada Wanita
Pelaku Penyimpangan Sosial Di Kota Padang. Jurnal Ilmu Kajian Gender Vol. IV No.1 Universitas Negeri Padang.

Henslin, J. M. 2007. Sosiologi dengan

Pendekatan Membumi. Jakarta: Erlangga.

Horton, Paul B. \& Chester L. Hunt. 1996. Sosiologi Jilid I. Erlangga. Jakarta.

Indrawati, Endang Sri. 2015. Status Sosial Ekonomi dan Intensitas Komunikasi Keluarga Pada Ibu Rumah Tangga Di Panggung Kidul Semarang Utara. Jurnal Psikologi Undip, Volume 14, Nomor: 1, April 2015.

Munawaroh, Faizatul. 2012. Konsep Diri, Intensitas Komunikasi Orang Tua-Anak, dan Kecenderungan Perilaku Seks Pranikah. Persona: Jurnal Pasikologi Indonesia, Volume 1, Nomor: 2, September 2012.

Muzaini. 2014. Perkembangan Teknologi Dan Perilaku Menyimpang Dalam Masyarakat Modern. Jurnal Pembangunan Pendidikan: Fondasi dan Aplikasi Volume 2, Nomor 1, 2014. Diakses di: http://download.portalgaruda.or g/article.php? article $=282397 \& \mathrm{v}$ $\mathrm{al}=437 \&$ title $=$ PERKEMBANG AN\%20TEKNOLOGI\%20DAN $\% 20$ PERILAKU\%20MENYIM PANG\%20DALAM\%20MASY ARAKAT\%20MODERN.

Nasikun. 2001. Sistem Sosial Budaya Indonesia. Raja Grafindo Persada. Jakarta

Puspitawati, Herien. 2013. Konsep Dan Teori Keluarga. Departemen Ilmu Keluarga dan Konsumen 
Fakultas Ekologi Manusia-

Institut Pertanian Bogo Diakses

di:

http://ikk.fema.ipb.ac.id/v2/imag es/karyailmiah/teori.pdf.

Rakhmad, Jalaluddin. 2012. Psikologi Komunikasi. Remaja Rosdakarya. Bandung.

Ritzer, George. Smart, Barry. 2012. Handbook Teori Sosial. Nusa Media. Bandung.

Satriani I., P. Muljono, R.W.E. Lumintang. 2011. Komunikasi Partisipatif Pada Program Pos Pemberdayaan Keluarga. Jurnal Komunikasi Pembangunan ISSN 1693-3699 Juni 2011, Vol.9, No.2. Bogor: IPB. http://journal.ipb .ac.id/index.php/jurnalkmp/articl e/ viewFile/ 9042/7108. Diakses pada hari Jumat, 2 Desember 2016, pukul: $02.38 \mathrm{pm}$

Suyanto, Bagong. Sutinah. 2005. Metode Penelitian Sosial. Berbagai Alternatif pendekatan. Prenada Media. Jakarta 